\title{
THE FUTURE OF MONETARY REFORM AND THE REAL ECONOMY: A PROBLEM OF TRADE VERSUS INTEREST
}

\author{
MASUDUL ALAM CHOUDHURY \\ College of Economics and Political Sciences \\ Sultan Qaboos University, Muscat Sultanate of Oman \\ SOFYAN SYAFRI HARAHAP \\ Director of Postgraduate Program in Islamic Economics and Finance \\ Trisakti University, Indonesia
}

\begin{abstract}
The prologue is our starting premise.

The Qur'an (2: 275) declares, "As for those who devour interest, they behave as the one whom Satan has confounded with his touch. Seized in this state they say: 'Trade is but a kind of interest', even though Allah has made trade lawful, and interest unlawful".
\end{abstract}

Keynes (1930, p. 368) picked up such wisdom of the inverse relationship between trade and interest and wrote, "The strenuous purposeful moneymakers may carry all of us along with them into the lap of economic abundance. But it will be those peoples, who can keep alive, and cultivate into a fuller perfection, the art of life itself and do not sell themselves for the means of life, who will be able to enjoy the abundance when it comes."

Such are the messages of moral highness and wisdom picked up in this paper. The fundamental point here is to establish the fact that the only way of phasing out interest rate from Islamic activities is to understand and implement the formalism of the inverse relationship that permanently exists between trade in the good things of life and the rate of interest as the impediment to the free flow of resources into such tradable activities.

The central bank and commercial banks and financial intermediaries as practitioners must understand this organic relational concept of intellection in relation to money and the real economy. The monetary system and the real economy with the financial instruments between would thus be shown to formalize the intellection paradigm - which indeed is a truly scientific revolution. The result is replacement of the fractional reserve requirement 
monetary system by the 100 per cent reserve requirement monetary system backed by the gold standard. Likewise, the organic relationships of such a monetary arrangement including its monetary policy and transmission mechanism would structurally change the nature of markets and its institutional relations and individual preferences. The result at the end will be a phased down interest rate regime into a trade-related one by the rise of the tradable relationships that are generated.

The foundational methodology that enters this kind of organically relational worldview with the episteme of unity of knowledge (the divine law in Islam) provides the functional ontology of the socially and morally constructed money, production and real economy circular causation. It models the legitimacy of trade as the resource mobilization instrument, while rejecting interest as the permanent impediment of resource mobilization.

Keywords: Monetary economics, Islamic economics and finance, Islamic political economy and world-system, social economics, ethics and economics.

\section{Introduction}

Often in recent economic and financial experience it has been proven that a low rate of interest by bank regulation, macroeconomic policy objectives, and market forces have ended in fiasco in stabilizing the economy. The low real rate of interest during the 1960s in the face of low nominal rate of interest fueled the subsequent increase in inflation and resulted in stagflationary economic periods (Siven, 1978). The recent macroeconomic policy to drive the nominal rate of interest to zero in Japan, as an example, resulted in non-performing loans that were abundantly provided to borrowers. Most starkly true, the subprime mortgage rates on real estate in southern United States resulted in an aggressive spirit of borrowing to fuel the housing boom that turned sour. ${ }^{1}$ The inference drawn is that a low or zero rate of interest is a necessary but not a sufficient condition for the road to economic bliss. Structural changes in the relationships between money, finance and market exchange must be established simultaneously with reduction in the rate of interest.

\section{Objective}

Our objective in this paper is to explain the necessary and sufficient conditions of economic and social bliss that is reached by the endogenous interaction between money, finance and the real economy. 
The idea of endogenous relations is conveyed by the systemic interrelations between entities and variables of the socioeconomic problem under study. These internal dynamics generate causality and learning by interaction. The concept is similar to what Paul Krugman termed as 'self-governing equilibrium' resulting in self-organized behaviour. The change occurs simultaneously with the phasing down of interest rates. This kind of total change is also tantamount to the pursuit of endogenous interrelationships between the central bank, the commercial banks and the market economy exchanging in the good things of life (Hayat tayyibah in the Qur'an) according to Islamic law (sharia).

The explanation of these kinds of changes is carried out in reference to a fundamental phenomenological model of unity of knowledge, upon which the Islamic world-system governing 'everything' permanently and indispensably stands. This is the epistemology of unity of knowledge and being (existence) (Tawhid), exemplifying the precept of the oneness of God, as this precept creates and governs the world-system. Within this kind of learning and unified world-system we study the endogenous relationships of pairing in unity between the economic and financial domains as mentioned above in respect of money, finance and the real economy. This methodological content is presented in the appendix.

\section{Zero Rate of Interest: A Necessary but Not Sufficient Instrument for an Islamic Economy}

In Malaysia for instance, a recent programme towards zero-inflation rate (cipher-inflasi) resulted in a mismatch between the subsequently high rates of interest and the zero rate of inflation (mid-nineties). When the Southeast Asia financial crisis hit Malaysia (mid-1990s) high interest rates were used as a macroeconomic monetary policy to invite foreign capital to shore up the declining exchange rate. But the relationship between interest rates and exchange rates remained volatile (Choudhury, 1999), suggesting that there is no way of stabilizing the exchange rates and inflation just by using the instrument of high rates of interest. Evidence does not support this.

Malaysia's experience with Islamic funds has soured in regards to their performance, for example the experience with the now diminishing mudaraba (profit-sharing) and musharaka (equity participation) forms of financing. Islamic banks and finance companies have withdrawn almost completely from these principal Islamic financial instruments. 
These instruments are replaced by secondary financial instruments, all of which are subject to sharia concerns (Choudhury, 2008a). Likewise, despite earnest efforts to promote Islamic financing and profitability in the face of interest-free financing of projects and investments, Islamic banks in Malaysia could not herald even a distinct prospect for the well-being of the ummah, the conscious world nation of Islam, in the field of Islamic networked flow and organization of institutions for resource sharing (trade). The assertion is borne out by the fact that Islamic banks and development planning in Malaysia never accounted for a clear direction of Islamic financing there towards ameliorating either her own broader Islamic global picture or the momentum of trade, development and related policy instrumentation for the Muslim bloc. The Islamic Development Bank Annual Reports for a long time now bring these out on the basis of communal trade statistics.

The current lure with sukuk (bonds that revolve around the principal financing instruments of mudaraba and musharaka) and the market of sale of musharaka-linked bonds in real assets to the private sector to finance mega projects, have ended up in deep sharia concerns (Usmani, see internet website). Sukuk financing problems arise from the sale of debt with interest to private outlets. The sukuk holders can then proportion this equity instrument between the government and private businesses through public shareholding. Consequently, the debt coverage in such projects passes on the debt as an intergenerational burden to debtor companies. An alternative would be for such companies to engage in debt-equity swaps (Krugman, 1989; Blackwell \& Nocera, 1989; Choudhury, 1989). Debt-equity swaps involve large investors to retire the debt or a part of it for an indebted country by paying it out in these proportions (i.e. investing to buy the debt). In exchange, the debt-ameliorated country treats such an investment as an equity swap for the debt retired. Debt-equity swaps can be managed effectively in the case of equity-participation (musharaka).

The debt overhang and the allowance for financing debt in the private sector is thus at best extended over time, rather than being a comprehensive financing mode that can be instituted for phasing out the interest rate regime caused by debt overhang. The goal of financing interest-bearing, debt-ridden projects by interest-free financing instruments therefore does not cure the interest-rate enigma. Thereby, the true impact of financing by Islamic participatory instruments is not reached, even when the interest-free goal is targeted to reach a 
given level of efficacy. Yet in the name of interest-free financing as the focus of Islamic finance, Islamic banks and finance companies, Muslim governments and large businesses and projects are raising the flag of sukuk (Gassner, 2008; Business Islamica, 2008).

\section{Capitalization of Income Flows and the Rate of Interest}

From the history of western economic thought we learn about alternatives to interest rates in asset valuation. Sraffa and Keynes referred to one such alternative interest rate as 'the own rate of interest' (Sraffa, 1932; Donzelli, 2004). Likewise, we note the arguments in support of the Austrian concept of money and interest rates (Wicksell, 1934). ${ }^{2}$

The first of the above-mentioned issues indicates that traditional economic theory, like the ones claiming the concept of 'own rate of interest', equated the rate of interest with the marginal productivity of capital or the marginal efficiency of investment. Wicksell's problem points out how the rate of interest is equivalently treated as a discount factor to evaluate capital-flow over time. Such notions have been used by Islamic economics and finance to erect their so-called 'rateof-return' concept according to the marginal productivity theory and the use of asset valuation based on discount-rate formulas. Islamic banks have adopted these rules thoroughly; Islamic gurus support it (Vogel \& Hayes, 1998).

One can also refer to the continued practice of such a time-value-ofmoney discounting mechanism now being carried out in the Islamic Development Bank and all Islamic banks around the world. This also confirms the of a survey of research departments and directors of the Islamic banks in Indonesia that was carried out by the author (mimeo. Islamic economics and finance: An epistemological inquiry, funded at the Sultan Qaboos University, College of Commerce and Economics, 2009).

The notion of a low interest rate or phased-down interest rate in economic and financial arrangements has prevailed in the literature. But the concept of how the rate of interest emerges in the economy, and how it can be phased out from this system, has not matured either in the mainstream literature and practice or within the theory and practice of Islamic economics and finance. The latter area thus remains inextricably submerged in mainstream academic thinking relating to money, interest rate and the real economy relations. The 
result of this intellectual debility is reflected in a flawed conception that is transmitted into the Islamic rules concerning worldly matters (Figh mu'amalat), Islamic financial institutions, and the conceptions underlying the academe of Islamic economics and finance.

The net result of these developments in the history of economic thought in respect of the theory of interest and capital accumulation, and which Islamic economics and finance have emulated, is this: Capital accumulation embodies savings arising from abstemiousness in present consumption for attaining maximum intertemporal consumer utility. This idea is embodied in the classical theory of intertemporal savings and consumption contributed by Ramsay (1928). The capitalized value of all future yields from present abstemiousness in consumption is obtained by a discounting method that invariably imputes the discount rate as the shadow rate of interest for capitalizing future uncertain yields.

\section{The Position of Islamic Economics and Finance in Respect of Capitalization of Assets with Interest-Free Instruments}

Islamic economic and finance gurus have adopted a time-value of money discounting approach in asset valuation. They thus failed to understand the interest-rate implications of the discounting approach. The result in asset valuation is that a future market, which remains undetermined, would be capitalized at a rate either less or greater than the expected rate of return on the stream of future income flows.

Especially, in such a case of discount-rate indeterminacy, microenterprises have difficulty in tying up commitment to a mark-up that determines the investors' and shareholders' dividends and profits. Microenterprises bear the burden of the excessive cost of capital. The problem arises when large shareholders aim at discounting their risk by taking a larger share of the profits in joint venture. This leaves smaller residual shares and dividends for the small borrowers and participants in Islamic funds. Microenterprises thus find it costly to refinance their assets by means of the lower share of total profits of joint ventures.

The same result can swing in favour of micro-enterprises at the expense of shareholders when an under-valuation of the intergenerational flow of projected returns takes place. In such a case, the question is this: Can the investor be risk-avert and divert potential investments into risk-free alternatives, such as short-term trade using the murabaha 
(mark-up) financing instrument? None of these alternatives comes to the benefit of socioeconomic development of the community, and beyond of the ummah. Indeed, a prevalent problem of Islamic banks is either a lack of investments or an over-subscription of shareholders' capital. These results are reflected in the variable, 'financing/ deposit ratio', which is found to move away on either side from the expected value of unity (Choudhury, 2009) in Islamic banks. Islamic banks in Indonesia show such financing problems in their annual reports (Bank Muamalat Annual Report, 2007; Bank Mandiri Annual Report, 2006).

Consequently, although interest-free financing has been promoted by Islamic banks, yet the method towards realizing this goal has not been well-defined in terms of investment, liquidity problem, asset valuation and socioeconomic development of the ummah. Besides, it was pointed out above that secondary financing instruments have been used in place of the principal Islamic financing instruments to argue in favour of operations in interest-free financing. Yet there are looming sharia problems relating to interest rates in these secondary financing instruments. Two of these problems are first, the absence of the idea of pooled funds made by combining individual types of financing modes. The sharia gurus have not looked into this possibility. The second one is the difference of the oft-used shariacompliance jargon from the great purpose of the sharia, the maqasid as-sharia (Mufeedh Choudhury, 2009).

Both of these approaches in asset valuation and financing run into the same kinds of methodological problems mentioned above. They generate ineffective socioeconomic development effects. A clear example is the almost negligible difference between Islamic banks and conventional banks in respect of such Islamic and conventional modes of financing. This situation is found to be empirically true of Islamic financing everywhere (Choudhury, 2008a).

\section{The Money, Finance and Real Economy Relationships in an Interest-Free Regime of Socioeconomic Change}

Islamic economists argue on behalf of establishing an interest-free regime of socioeconomic change by retaining the existing fractional monetary reserve system, despite introducing the compelling need for delivering social justice (Chapra, 1985). The arguments, prescriptions and implementation of such an approach through interest-free targeting are untenable. We explain this problem below in terms of a general system of comprehensive socioeconomic transformation. 
Further details on the analytical version of the general-equilibrium system are given by Choudhury (1997). The idea expressed in this reference and similar references is that interactive, and thus unifying relations between an expanding economic and financial system, cause systemic learning, that is evolutionary-type equilibriums with complementarities. The result is heightened participation causing empowerment for the participants.

If interest-based financing is inverted by the rise of trade-based instruments in the Islamic case, then there is a decreasing need and incentive for holding savings in banks and capital markets. Consequently, Islamic banks become outlets of mobilizing savings continuously into spending in the good and productive things of life (referred to as Hayat tayyibah in the Qur'an). This process, which is continuous, generates participatory dynamics between spending possibilities (relations) and between their entities (representative variables denoting socioeconomic variables and financing instrumental variables). These variables define the relations and represent the agencies (agents, institutions, markets, etc., underlying the relations and their constituent variables). Indeed, the Islamic world-system, within which are studied the complementary relations between money, finance and the real economy is fully participatory in nature (Choudhury, Zaman \& Harahap, 2008).

The result then is to interactively integrate the three domains money, finance and the real economy in participatory ways, so that they learn by circular causation between them. Such causation is the same as generating endogenous relations between the representative pairing variables. Indeed, pairing is the Qur'anic message of pervasive complementarities between entities and their representative variables. The circular-causation phenomenon is termed equivalently as learning behaviour in the midst of complementary relations. The pervasive principle of extensive complementarities is the clearest sign of unity of knowledge, which denotes the epistemological premise of money, finance and the real economy system of circular causation relations. The epistemology of unity of knowledge, forming the complete phenomenology of the socio-scientific system will be formalized below. The result is a formalism that is 'universal' and 'unique' in conception and application. In the present case, we study the money, finance and the real economy complementary circular causation relations according to the same epistemology of unity of knowledge as derived from the Qur'an in reference to the oneness of 
God as functional ontology working in the experiential order. This epistemology is understood in this paper equivalently as the unity of the divine law that causes unity in the world-system.

The argument here is that phasing out the rate of interest in Islamic financing can neither be sustainable in the absence of a simultaneous overhaul of the monetary system in relation to the real economy, nor will the ruptured goal of unity between money, finance and the real economy lead to the realization of anything that is truly Islamic in the ummah sense. The latter argument here was explained earlier by examples in the contemporary history of Islamic economic thought and action in reference to its imitation of the Occidental worldview.

The Occidental economic thought did vouch for the developmentfinancing regimes devoid of the interest-rate (Sauer, 2002), but with a failed conception. Likewise, at the present time of global financial and banking crisis, central banks in most countries are lowering their prime rates to zero to bring about lower bank-lending rates and stimulate spending. Yet we cannot say that these economies and the banking system have been transformed into the Islamic banking and finance kinds. The fact is that interest-rate reduction to zero can be attained independently of structural change. Such is the case with Islamic banks today. They follow the idea of 'sharia-compliance' instead of focusing on and rising up from the foundation of maqasid as-sharia (the purpose and objective of the sharia). Consequently, no structural change has come about in a substantively foundational way for the ummah. Only a small segment of the financial sector (less than 2 per cent of the global capital market) remains relatively free of interest-based transactions. See (M. Parker in Arab News, 3 Jan. 2012) for supportive facts.

How can an Islamic capital market arise? The fundamental transformation into the money, finance and the real economy complementary linkages remains hampered by the blockage in the flow of resources in the mere presence of the 'sharia-compliance' idea. A better possibility for realizing the impact of interest-free financing in the real economy is to establish the wide range of linkages that money-finance-real economy interrelations generate and are sustained.

Therefore, to base all transactions on interest-free instruments in the Islamic economic and financial system is only a necessary condition of Islamizing the financing and banking system. By itself the abolition 
of interest financing is not a sufficient condition in establishing the alternative of trade and participatory development in the Islamic ummah. It is therefore necessary to combine the interest-free transformation as a process linked with a simultaneous change in monetary policies and money-finance-real economy relations. Such relations are generated between the central bank, the commercial bank and the real economy by circular causation. The resulting new economic arrangement based on complementary circular causation between variables and their representative agents would cause the emergence of unified, synergetic interrelationships between the monetary system, the financial instrumentation and the real economy. We now turn to a formalism of the underlying dynamics in such a case.

\section{The Circular Causation between the Central Bank, Commercial Banks and the Real Economy in the Midst of Money, Finance and Real Economy Relations}

Consider the resource flows in Figure 1. The circular connections and the two-way arrows explain the circular-causation relations between the various entities as noted. Most importantly, in this kind of circular-causation relationships there occurs the simultaneously complementary and participatory linkages between the central bank, the commercial banks (Islamic banks and other banks), and the resulting complementarities in the real economy between the good things of life as ordained by the sharia. Such unifying relationships bring out the nature of monetary policy and the complementary money, finance and market transformation in the Islamic economy.

The Islamic economy is essentially based on free-market orientation. But at the same time, it is guided by knowledge induction and appropriate sharia instruments and policies to realize resource mobilization into the good things of life. In this respect, the central bank generates a supply of money as is conventionally known. That is, the supply of money to banks in excess reserve pursues multiple credit creation backed by promissory notes. Also, the intent of the underlying monetary policy is to attain a stable and productive macroeconomic state of the general (circular) flows of goods and services in physical and monetary terms.

In the Islamic case, the concept of money supply is replaced by the concept of 'quantity of micro-money' pursuing the needs of specific projects that are based on the maqasid as-sharia. The concepts of 
demand and supply of money are now replaced by that of 'quantity of micro-money specific to approved projects'. In other words, such projects are financed by the full quantum circulation of micro-money in specific projects, as needed.

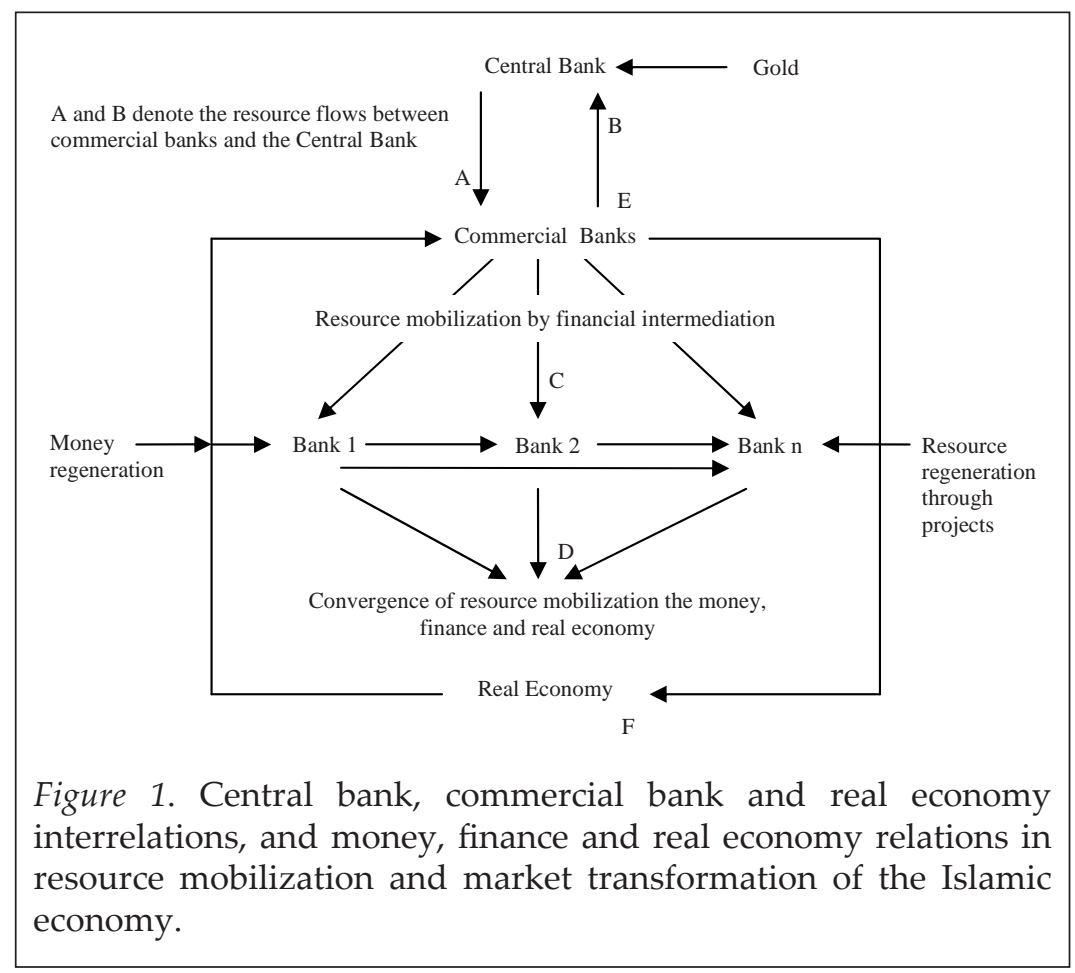

Explaining Figure 1: The central bank, commercial banks and real economy linkages

In Figure 1, the label ' $\mathrm{A}$ ' denotes injection of funds as a quantity of currency $(\downarrow)$. Currency is thereby equivalent to money serving as a medium of satisfying the additional demand of commercial banks to finance real economy project-specific development in a situation where market demand for funds exceeds the available financial resources to fund the projects. The point here is that resource mobilization through the commercial banks (Islamic banks) will run its own course through the real economy.

Through such a currency flow, a quantity of micro-money is linked up with market exchange by the use of financial instruments. Real 
bills can be endogenously generated by commercial banks under the authority of the central bank (Green, 1989). Now there would be an automatic equilibrium circulation of currency through the commercial banks entering the real economy. This kind of an equilibrium process of money-finance-real resource linkage must however be governed by appropriate central bank regulations on sustaining a stable and growing economy.

We note in such a case, there is no excess creation of money by the central bank when an automatic equilibrium process is maintained between the monetary flows generated by linkages between the commercial banks and the real economy. The commercial banks under the authority of central bank guidance can generate the real bills for the increased resource mobilization as needed. Alternatively, it is possible that central banks create the extra quantity of money needed to finance a growing real economy. The cost underlying this additional flow of a quantity of money will be recovered from bank seigniorage. Seigniorage is revenue gained by the central bank to cover the cost of producing a quantity of money by gold-backing. The cost will be collected from the borrowing commercial banks that themselves earn participatory returns from the yields of the real economy funding of projects, also from market exchange in approved goods and services. The central bank and commercial bank interrelationship abides. The quantity of money required to finance additional projects in the real economy arises from the increased demand for goods and services that result in project development.

Such an automatic circulation of money into projects - hence the name micro-money (Choudhury \& Hoque, 2004) - in relation to the real economy, is shown in Figure 1 by the circular direction of arrows $(\rightarrow)$. The direction of the arrow indicates the mobilization of monetary and real resources between banks and the real economy.

On the one side, there is the quantity of goods and services in demand. On the other side, this real economy demand is satisfied by the monetary injection. This injection of money equals a quantity of currency in circulation. The carrier of this circularly regenerated monetary stock through the real economy in response to the demand for regenerated resources, comprise the bundle of trade-related instruments. Trade and commerce thereby replace interest-based businesses of all kinds. ${ }^{3}$ The principal meaning and objective of the quantity of money now becomes the need for currency to finance productive and appropriate projects in response to the increased 
demand for the corresponding kinds of goods and services connected with such approved projects in the light of the sharia. An effective transmission of money through financial instruments would thus take place to finance the real economy of goods, services and projects in the light of the shari'a.

The result thus is contra-bank savings. We mean by bank savings that part of the earned and national income that is withheld by banks to serve interest-bearing and speculative portfolio over time. ${ }^{4}$ Now, just as trade increases, the flow of resource into the real economy is enhanced. The quantity of micro-money increases in pursuit of such a real demand for goods and services connected with projects. The diversion of income into bank savings to earn interest rate is diminished. This kind of internal adjustment in the financing medium brings out the logical and formal basis of trade, thus positively affecting resource mobilization through the market-oriented real economic transformation with linkage to monetary flows through financing instruments. The consequence of this kind of circular flow dynamics is a continuous liquidation of savings at every moment of time in the life of the economy by its mobilization into approved spending outlets.

However, when the total financing cannot be done by the available bank deposits by households (wherein savings = resource mobilization), the banks call for additional financing from shareholders and depositors and the expansion of a quantity of money by the central bank loaned out to the commercial banks. In such a case, the (financing/deposit)ratio exceeds unity. The principal shareholder/stakeholder of the Islamic banks, in the sense of the lender of last resort, is the central bank. Besides, other principal shareholders' share-capital can be secured in the central bank for the benefit of lending to commercial banks in the situation of excess demand for funds to finance approved projects. These parts of the monetary flow are included in label ' $A$ ' in Figure 1.

There is yet another type of monetary flow between the commercial banks and the central bank. When the demand for money to finance projects declines due to lower market demand, the 'excess reserve' in commercial banks is liquidated. The resulting amount of unmobilized financial resources cannot remain in the commercial banks. The commercial banks are not allowed to hold this saving as excess reserve, for fear of causing multiple credit creation. Excess reserves held in commercial banks will otherwise negate the above-mentioned 
dynamics of trade over saving in regenerating resources and the quantity of micro-money to meet real demand for goods, services and projects. The unutilized savings must thus be deposited fully as 'reserve' with the central bank. Such central bank reserve transfer form simply stock of unmobilized monetary stock now held with the central bank. They will form Islamic instruments once they are mobilized through the commercial banks upon demand. The fund remains with the central bank until it is called back by the commercial banks to finance subsequent rounds of enhanced demand in the real economy. This mechanism is shown at the point ' $\mathrm{B}$ ' in Figure 1.

\section{A Simple Version of Financial Flows between the Central Bank, Commercial Banks and Real Economy}

A simple form of the financial flows schema through the monetary and real economy linkage can be seen in Figure 2. The following symbols are defined: The important idea here is to convey the dynamics of circular links between money, finance and the real economy that generate the cause and effect of sustained resource flow in monetary and physical terms by circularly interrelating them.

$r_{i^{\prime}}, i=1,2, . ., n$ denotes the ith resource outlet, e.g. food, real estate, cultivation (micro-level)

$\mathrm{x}_{\mathrm{i}^{\prime}}, \mathrm{i}=1,2, . ., \mathrm{n}$ denotes unit investment on the ith resource outlet; i.e. per unit of the spending outlet

$r_{i} \cdot x_{i}$ denotes the total investment on the ith resource outlet

$\mathrm{g}_{\mathrm{i} 1}$ denotes growth obtained by developing $\mathrm{r}_{\mathrm{i}}$

$\mathrm{g}_{\mathrm{i} 2}$ denotes expansion by growth of $\mathrm{x}_{\mathrm{i}}$

$\mathbf{R}$ denotes the total regenerated resources following monetary circulation by financial intermediation across projects financed by the consortium of m-number of banks and shareholders in the real economy

$\mathrm{P}_{\mathrm{i}}$ denotes the n-number of projects financed by banks

As the circular flow of resources continues over time across several projects with their increasing product and risk diversifications, so also the resources get augmented by compounding of $\left(1+\mathrm{g}_{\mathrm{i} 1}+\mathrm{g}_{\mathrm{i} 2}\right)$ over time. ${ }^{5}$ Commercial banks can now supply real bills as currency to finance the augmented resource development. As long as the augmented financial resources following the real economy growth denoted by $\left(1+\mathrm{g}_{\mathrm{i} 1}+\mathrm{g}_{\mathrm{i} 2}\right)$ continue over time there is no reason to go into the fractional reserve requirement monetary system. All the generated resources remain with the commercial bank across specific projects. 
The central bank holds none of the statutory reserve. This though is the ideal case of 100 per cent utilization of commercial bank real bills in the real economy in pursuit of approved possibilities.

The initial amount of $\$ 1,000$ from the central bank is the case where the investment demand in the real economy is high and the commercial banks fall short of this amount to finance all projects. Consequently, the (financing/deposit)-ratio exceeds unity.

We next examine the possibility of resource leakage from the banking system. The important issue here is to note that the quantity of money exists in circularity between the demand of the real sector, the availability of loanable funds with the banks, and the additional requirements from the Central bank. In the last case, certain amounts of funds could fail to meet the optimal requirements of the real economy, thus causing leakages from the desired money, finance and the real economy interrelationship. Indeed, the usual case of resource mobilization must accept leakages through the commercial banks in the real economy linkages with financial instruments carrying money. Consequently, the resulting contraction of yields in the real economy allows for say, $\$ 900$ resource mobilization. This would then cause $\$ 100$ to remain as savings in the commercial banks to yield interest income on idle financial resources when fractional reserves return. Thereby, the inter-bank flows of such savings in speculative assets will trigger multiple credit creation and an accumulating amount of interest cost on debt capital.

To avoid such a situation when the resources are not fully mobilized into the real economy, the commercial banks hand over the $\$ 100$ unutilized financial resource to the central bank for safe-keeping. This becomes the 100 per cent potential reserve of the commercial bank with the central bank. Note here that this definition of the $100 \%$ Reserve Requirement Monetary System (RRMS) with the gold standard (explained below), is quite different from the 100 per cent reserve requirement monetary idea explained in the literature (Rist, 1940; Friedman, 1968).

The commercial bank would use this 'saved' resource at a later date on the basis of its legitimate claim based on credit-worthiness due to increased possibility in financing diversified projects. At the time of such a future release of funds from the central bank, the 100 per cent reserve converts to money in circulation in the form of a quantity of currency. 
The central bank is entrusted with the protection of the value of the underutilized resources through the commercial banks. This value protection cannot be done by paper and promissory notes or any such numeraire whose long-term stability is in question. The choice is gold as the required stable monetary numeraire. The long-term stability of gold has been proven historically (Choudhury \& Hoque, op cit). Thus a stock of gold denoted by $\mathrm{G}$ is stored by the central bank to stabilize the value of the central bank reserve, which subsequently becomes currency in circulation.

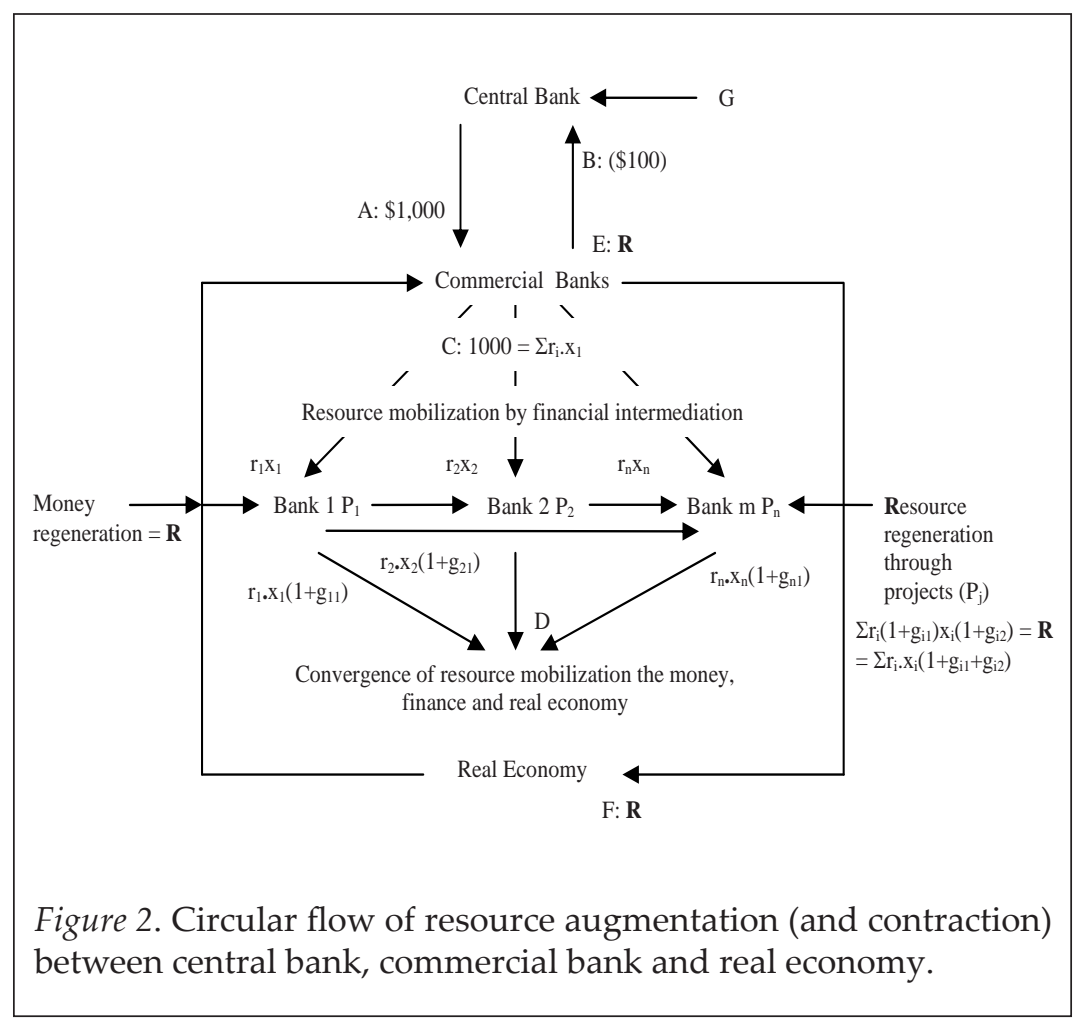

Let the change of gold stock be denoted by DG (which in the special case equals the initial new stock G). Let DM denote the 100 per cent reserve with the central bank. Let $\mathrm{p}_{\mathrm{G}}$ denote the price of gold. For maintaining stability of the monetary stock, that is 100 per cent reserve with the central bank, the condition is

$$
\mathrm{p}_{\mathrm{G}} \cdot \Delta \mathrm{G}=\Delta \mathrm{M}
$$


But DM would ultimately add to the currency stock (DC) when DM is re-injected into the real economy on demand. Thus,

$$
\mathrm{p}_{\mathrm{G}} \cdot \Delta \mathrm{G}=\Delta \mathrm{M}=\Delta \mathrm{C} \text {. }
$$

Thereby, $\Delta \mathrm{C} / \Delta \mathrm{G}=\mathrm{p}_{\mathrm{G}}$.

Now by 'mathematical integration' over the entire stock of currency, and thereby of the gold stock, with the condition that $\mathrm{G}=0$, when $\mathrm{C}=$ $\mathrm{M}=0$, $\mathrm{M}$ being the money held by the central bank under the 100 per cent reserve requirements monetary system, it is true that:

$$
\begin{aligned}
& \Delta \mathrm{C} / \Delta \mathrm{G}=\mathrm{p}_{\mathrm{G}^{\prime}} \\
& \text { so also } \mathrm{C} / \mathrm{G}=\mathrm{p}_{\mathrm{G}} .
\end{aligned}
$$

This proves that the value of gold that protects the marginal amount of money by a corresponding marginal amount of gold stock also simultaneously protects the entire currency as money in circulation in the real economy. Thus only effective pricing in the real economy values the currency value per unit of gold-backing of temporarily unmobilized commercial bank reserve held with the central bank as $100 \%$ RRMS.

\section{Central Bank Functions in 100\%RRMS}

The conclusion now is astounding. A small amount of gold is needed to protect the entire stock of currency in circulation. The regulatory condition though is this: The central bank must regulate the stable price of gold over the long-run. Stability of gold price can be maintained by regulating the stock of gold in the economy/society. The Islamic state has the duty of moral suasion to attain such a goal of moderation on holding gold as precious metal. The same kind of regulation is extended to the mixed precious bi-metals, gold and silver.

In the $100 \%$ RRMS, the role of the central bank in monetary management is reduced to policy-making and regulation for supervising a sustainable market economy in approved goods, services and projects. This situation would involve supervising the management of a stable and growing economy in concert with the participation of commercial banks as the principal medium for mobilizing money and finance between banks, the financial sector and the real economy. 
The power of creating money by the central bank is reduced to managing a stock of gold to maintain the value of money as currency in circulation (see Money Matters on 100\%RRMS, internet version). This function too is inversely related with the velocity and volume of the circularly mobilized money and finance through the real economy (Figures 1 and 2).

Gaining from the extensively participatory nature of the 100\%RRMS and the real economy, the central bank also engages in a continuous activity of knowledge sharing with the central bank and the agents representing the real economy. This generates an overarching 'Learning Process' towards determining the general-system relations involving the central bank, the commercial banks and the real economy. Thereby, technical analysis, the resulting information sharing, and development of such learnt policies and endogenous learning experience become the principal attributes in central bank function in the money, finance and real economy interrelationships with 100\% RRMS.

All functions conventionally endowed on the central bank cease to have effect. Governance is replaced by the participatory decisionmaking analytical forums. The conventional functions on the other hand are money supply and monetary regulation, interest rate and exchange-rate setting by regulating the monetary reserve of the countries, balance of payments. All these targets are converted into endogenous causality in our 100\%RRMS. Inflation targeting too is left to market adjustment in the midst of the features of 100\%RRMS with the gold standard and the micro-monetary perspective of project financing.

\section{The Laissez Faire Concept of Money and Medium of Exchange in the Literature}

Our delineation of a predominantly commercial-banking role in resource mobilization in the real economy with the central bank being a lender of last resort and an overseer of the currency value in market exchange in terms of a quantity of gold-backing, has strong precedence in the literature (Saving, 1977; Klein, 1975; Tullock, 1976; Tobin, 1963). Hayek thought about such a kind of private monetary system in which private banks will play the role of money circulation (Hayek, 1976). In this case, private money would all be valued on the basis of a given standard, such as gold, but they would compete with each other. In other words, competing quantities of money would be held by private institutions, especially banks, and this would be like holding money in terms of financial and other assets. 
Yeager (1997, pp. 412-413) writes in regards to privately supplied money. Commercial banks would supply such funds. The central bank's authority in such a monetary system would be minimal. This is his prescription of monetary reform, which Yeager expands upon the work of Black, Fama and Hall - BFH (Yeager, 1983):

Government would be banished from any role in the monetary system other than that of defining a unit of account or numeraire. We envisage a unit defined by a bundle of goods and services comprehensive enough for the general level of prices quoted in it to be practically steady. Merely by conducting its own accounting and transactions in the Unit - we tentatively so name it, with a capital $\mathrm{U}$ - the government would give private parties a strong incentive to adopt the same Unit.

Yeager continues (op cit, p. 413):

No longer would the size of the numeraire, one Unit, be determined by the supply and demand for any medium of exchange. The Unit would be defined by goods and services having supplies and demands of an almost entirely non-monetary character.

\section{The Praxis of the Islamic Approach to Trade and Interest Relationship}

Our arguments establish the fact that interest-rate eradication in the Islamic economy cannot be enforced by exogenous forces, policies and measures. If it is so, as is presently practiced by Islamic venues everywhere in the world, the replacement of the interest rate will not be sustained without simultaneously charting the constructive change that the trade and financing instruments must generate between money, finance and the real economy. Presently, there is no such attempt by Islamic banks and Muslim countries in their Islamization experiment. Consequently, the programme of Islamization of the financial sector has not proceeded to the extent of contributing to the rise of the ummah endowed by its own capital markets, intercommunal international trade dynamics, and socioeconomic development programmes. This is the continued import of idea from our earlier mention. That is, merely a construal of interest-free financing modes does not form an adequate benchmark of the sharia. Islamization is not an adequate approach in such a partial view of Islamic change. The ummatic view, in which money, finance and real economy interrelationships play the crucial role of structural 
change and monetary reform must emanate from the general-system objective based on the epistemology of systemic unity of knowledge.

We have argued and explained that the Islamic programme to phase out interest rate, and replace them with trade instruments ${ }^{6}$ must be carried out within a general equilibrium system of circular causal relations between money, finance and the real economy. This simultaneously involves pervasively complementary interrelations between the central bank, the commercial banks and the 100 per cent reserve requirements monetary system with the gold numeraire. Such pervasively complementary relations generate organic relations in reference to the epistemology of systemic unity of knowledge.

Thus the question arises: Can the central principle of pervasive complementarities be derived from any other epistemological premise other than the Qur'anic foundations? We note here the empirical and policy-directional role played by the principle of pervasive complementarities in explaining the epistemology of unity of knowledge by using the constructed functional ontology of that unity in diverse problems of the world-system. ${ }^{7}$ In this paper we have narrowed down such a problem treatment to money, finance and real economy participatory unity of relations.

The answer to our above question is in the negative. The dividing line between Islam and all other systems is the penultimate quintessence of epistemological reference to the oneness of God, or equivalently, the oneness of the divine law, which projects the unity of knowledge in relation to the world-system. In all other systems the origin of knowledge is premised on the epistemology of rationalism. Rationalism and its entire constructed system operate on the basis of methodological individualism, conflict, competition and notions of scarcity of resources, and thereby, of substitution between contested entities. The rationalist mind is inextricably rooted in such behaviour at the level of the individual, institution, society and human relations. Such a character remains globally at large in this rationalist worldsystem. Even socio-scientific theories and programmes of rationalist origin stand upon this nature of the world-system and 'everything' in it (Barrow, 1991; von Mises, 1978; Choudhury, 2008b).

\section{Extending the Arguments to the Open Economy Case}

Two cases need to be studied here. The first one is when a regional group together adopts a common currency. Such an arrangement is gaining momentum. It is voiced strongly by Mundell (2000) in respect 
of his prescription for a one world-currency. Likewise, there is the Euro, the American dollar, and a growing interest in a common Gulf Cooperation Council (GCC) currency following the inception of a future GCC common market and monetary union. In our case, the example is of an incomplete regional arrangement for the 100 per cent reserve requirements with the gold standard.

In the latter case, the fractional reserve monetary system is treated as dual with the Islamic banking system. Segmented markets would be necessary to establish the desired money, finance and the real economy interrelations. This kind of an incomplete monetary transformation is presently practised by some Islamic financial outlets, notably the Islamic Bank Bangladesh and the Islamic Society of North America Housing Co-operative. In general, the phasing out of interest rates in Islamic financial operations is embedded in a general system of simulated interrelations that must be realized with the simultaneous development of the emergent trade versus interest paradigm.

Following such a recent development, a return to the 100 per cent reserve requirement monetary system with the gold standard would be extended within the segmented region that would adopt this arrangement. The principle of resource mobilization is promoted in this regional grouping to establish a complementary and participatory trade and development regime. A regulatory and learning medium is enhanced by means of active networking between partners and Islamic banks.

A given stock of gold is parcelled through the medium of an Islamic bank for settlement of payments. This is a significant global project that can be considered by the Islamic Development Bank. Since the stock of gold required for stabilizing currencies would not be great, and would be inversely proportional to the extent and speed of resource mobilization, a large stock of gold and its minting cost would be avoided. Besides, the cost of gold minting would be covered by the seigniorage that the central bank would collect from the commercial banks in terms of the cost of production of gold required to protect the currency value and a legitimate mark-up (Black, 1989) of the reserve held. Seigniorage would also be collected by participatory arrangements that would exist in a cooperative agreement to share risk and returns between the central bank and commercial banks, and between the commercial banks and the clientele in the real economy. The latter case is well-known in the profit-loss (mudaraba) and equity participation (musharaka) arrangements of Islamic banks. 
For the participatory sharing of risk and return between the central bank and the commercial banks the resulting seigniorage arises in the case of partial resource mobilization by the commercial banks. Now the commercial banks share the services that the central bank renders by paying for these services in terms of the cost of procuring gold stock by the central bank plus a service charge on the commercial banks. The commercial banks can roll over this cost to their clientele in the real economy by way of service charges. This shows that both service charges and interest rates are inversely related to productivity and product and risk diversifications. These positive changes are causally related to resource mobilization through commercial banks. The principal cost that would exist is caused by leakages. This is where the full productivity of the use of money and finance in the real economy fails - always, partially, but increasingly so in the interestbearing system. In order to reduce such leakages and share in the full realization of profitability and cost-reduction, Islamic banks benefit from the joint consequences of risk and product diversifications. These conditions always exist effectively in a joint pursuit of resource mobilization, which is exemplified by the Islamic economic and financial system.

The paradigm of the participatory, thus endogenous relations between the central bank, commercial banks (Islamic banks) and the real economy remains unchanged for the open economy, as is the case with the closed domestic economy. In the open economy case, the national central bank, commercial and real economy relations are further extended by the bank of international settlements of payments in the Islamic networked monetary arrangement. Figures 1 and 2 are now extended to incorporate the additional monetary institution of international monetary settlement.

\section{Productivity-determined Exchange Rate in 100\%RRMS with the Gold Standard}

The exchange rate (E) is defined on grounds of productivity, avoiding the monetary intervention except in exigency of under-mobilization of financial resources. The following formula reflects this:

$$
\text { Terms-of-trade, } t=p_{X} \cdot X / p_{M} \cdot M \text {. }
$$

$X$ denotes volume of exports; $\mathrm{p}_{\mathrm{X}}$ denotes price export.

$\mathrm{M}$ denotes volume of imports; $\mathrm{p}_{\mathrm{M}}$ denotes price of imports. 
Rewrite equation (6) as,

$$
E=p_{X} / p_{M}=t .(M / X) \text { is the nominal exchange rate. }
$$

Because $\mathrm{X}$ and $\mathrm{M}$ are both determined by their similar dynamics within the country-specific or region-specific 100 per cent reserve requirement monetary system with the gold standard, therefore, $(\mathrm{M} / \mathrm{X})$ assumes a stable value, say ' $a$ '. Thereby,

$$
\mathrm{E}=\mathrm{a} . \mathrm{t}
$$

E defines the exchange rate. It is shown to have a stable relationship with the terms-of-trade variable.

As free trade expands between partners in the region with full or partial 100\%RRMS with the gold standard, as explained above, then $\mathrm{M} / \mathrm{X}$ tends to 1 . Hence trade liberalization along with a phase of transformation into a 100\%RRMS arrangement within and across the integrating region, result in stability of the exchange rate and the terms-of trade simultaneously.

It is implied from our continuing formalism below that with greater speed of economic integration, institutional networking of every kind, technological diffusion, factor mobility, and production and risk diversifications in the midst of the 100\%RRMS arrangement, expression (8) will cause an upward trend in $t$, and thereby, in E. The coefficient ' $a$ ' will be induced by the force of economic integration, which in our case of participatory trade and development, is based on learning and endogenous interrelations in the spirit of systemic unity of knowledge.

\section{The Functions of Money in the $100 \%$ RRMS}

The resourcemobilization issuein tradeversusfinancial interestimplies that increased complementarities in the system are required so as to simulate the well-being that is attained from such complementarities over learning processes. The function of money, finance and Islamic banks is precisely to attain this well-being objective. So what are the functions of monetary aggregate in such a system?

Is money a store of value? The value of money arises from the real economy in terms of approved exchange of goods, services and project financing. The absence of store of value in money means that 
there is no productive value in money as such. Rather, the stability of currency value in international exchange is attained by means of the gold standard in the way as we have explained for the 100\%RRMS in money, finance and real economy circular interrelationships.

Is money a unit of exchange? Yes, this is true; for money in $100 \%$ RRMS determines the true relationship between the unit value of money and the price of goods and services in exchange. Currency is equivalent to money in circulation in this system. This amount of money in circulation is supported by the gold standard in order to be stable and sound money as currency (von Mises, 1981). Indeed, the Prophet informally denominated various values to monetary units called danaq and mithqal, in terms of physical units of basic needs (Allouche, 1994). The importance of denominations of weights and measures appears in the Qur'an (83:1): “Woe to the defaulters in weights and measures, those who take full measure when they take from men and who give less when they measure out to them or weigh to them."

Is money a medium of exchange? This property of money is true only in the static case. In the intertemporal case of resource mobilization it is difficult to ascertain the state of demand and supply of goods and services at future time-periods. It is also difficult to ascertain the risk-contingencies that exist at future points of time. Also, consumer preferences, systemic risk, and costs of future flows of goods and services, and financial demand in projects are based on subjective factors, and are thus undeterminable. Consequently, it is impossible to ascertain the value of goods and services in exchange, and thereby, the value of money that would back up such a real economic value.

Therefore, money does not have any market of its own, which otherwise results in the theory of interest rate as the price of money and financial instruments. Islamic money being micro-money and specific to projects that need to be financed, the quantity of money (currency) in circulation in the economy is determined by full quantum flows into projects. We write the relations in this case between micro-money and project-specific financing as,

$$
\mathrm{MxV}=\mathrm{Pxy}, \text { or } \mathrm{M}=(\mathrm{Pxy}) / \mathrm{V}
$$

When $\mathrm{V}=1$, or 100 per cent circulation (full micro-money mobilization through banks), then,

$$
\mathrm{M}=\mathrm{Pxy}
$$


Expression (9) means that the value of a stock of micro-money equals the total spending value in terms of the prices and quantities of approved goods and services in exchange pertaining to specific projects (activity).

Note that ' $y$ ' denotes real output. Thus an alternative definition of money is the value of GDP, which in turn represents the value of all spending (expenditures). But all these implications are specified by projects, rather than by the economy as a whole. We therefore, interpret that a quantity of money, $\mathrm{M}$, is driven fully into financing a project(s). This is the meaning of full quantum financing of projects by micro-money.

Hence, $V \cong 1$. This is equivalent to the consequence of $100 \%$ RRMS, in which, any saved (unmobilized money as currency) is totally surrendered to the central bank. Otherwise, the micro-money as currency is totally mobilized as resource to fit into projects in the real economy.

We can write equation (10) in the light of the project-specific condition of micro-money transmission $\left(\mathrm{M}^{*}\right)$ through commercial bans as,

$$
\mathrm{M}^{*}=\sum_{\mathrm{i}} \mathrm{M}_{\mathrm{i}}=\sum \mathrm{P} \cdot \mathrm{y}_{\mathrm{i}}=\mathrm{P} \cdot \mathrm{y} \text { for economy-wide case }
$$

These kinds of project-specific circulation of micro-monetary 'units' were considered by Yeager (1983) in his laissez-faire approach to monetary reform. Yeager's Unit of money and Hayek's (1976) competitive currency units are weighted against a bundle of goods and services whose prices remain stable by supply and demand in market exchange against the value of the currencies used as monetary units for denoting exchange value of real goods and services. This kind of currency valuation against the real goods and services in market exchange can be used both in the regional and international sense. For example, units of currency can be the Islamic Dinar. The common commodity base for valuation is gold and silver in the 100\%RRMS with the gold standard.

Yet the currencies in circulation may not be strictly in these precious metals. Any government-certified way of holding money as a means of settling payments nationally, regionally, and internationally can be protected by the minting of the 'residual' stock of gold, G, shown in Figure 2. 


\section{In the end: Functions of Money}

We have debated against the notions of demand and supply of money, and replaced the concept of quantity of micro-money mobilized into projects through the banking sector in complementary relations with the real economy and by appropriate participatory financing instruments. This paper has also rejected the unquestioned acceptance of the notions of the mainstream functions of money. Of these, only the function of unit of exchange as it is actually realized or intertemporally established with market transactions is acceptable. The function of store of value is untenable, for value is jointly claimed by money and market exchange of real goods and services as they are temporally realized and as payments are settled. The function of money as the medium of exchange is rejected in the absence of a well determines of the exchange values of goods and services over time.

Ludwig Von-Mises (1981, p. 84) writes in regards to the notion of money as a medium of exchange (slightly edited):

Its (state) task thus becomes that of determining, in accordance with the intent of the contracting parties, what is to be understood by money in commercial transactions. From the legal point of view, money is not the common medium of exchange, but the common medium of payment of debt settlement.

In this paper, we have gone a step further by arguing that money is a convention to settle payment contracts at every determined moment of clearly realized market exchange in the real economy.

\section{Conclusion: Inferences on the Islamic Alternative on Global Financial Crisis}

Islamic banks are claimed to have remained safe from the financial crisis that is sweeping the world today. Central banks of most countries have cut down their prime lending rates to near zero to stimulate consumer and investment lending. Yet the deepening crisis continues. Islamic banks although insulated from the global financial crisis due to their operations that do not involve the stock market and speculative financing, have not gained advantage of the situation to contribute to the ummah future, and thereby, to show the path out of the crisis for the rest of the world, except by pointing out the zerointerest agenda and the alternative trade financing instruments. 
This paper argued that reducing the interest towards zero is not a new recommendation of any economic system during financial crisis. Spending and innovation require venture capital to be freely mobilized by development-financing instruments through commercial banks. Yet such a central bank policy is not taking effect toward stabilizing the global financial system.

This paper points out that simultaneously with the phasing out of interest rate to zero, it is necessary to reconstruct the general-system design of the relations between the central bank, the commercial bank, and the real economy. Within such general-system reconstruction must be taken up all such circular causation synergies that establish pervasive complementarities between the productive and good things of life that are not simply sharia-compliant but also meet the demands of the greater purpose of well-being that is embedded in the purpose of the sharia (maqasid as-sharia). This is a panacea for the Muslim and non-Muslim alike - because unethical, unsocial, and thereby, immoral things equally abhor all peoples and cultures.

Most fundamentally, underlying this common heritage of mankind upon which to build, renew, or reconstruct old and fallen systems is the epistemological shift away from rationalism. Rationalism breeds methodological individualism. Contrarily, the epistemology of systemic unity of knowledge as the core of unity of the divine laws in relation to the world-systems, establishes the world-systems on the foothold of cooperation. Discourse with convergence towards consensus is the goal and the result universally.

Discourse leads to new patterns of monetary futures. The global financial crisis requires a change in the monetary arrangements along with fiscal stimulus through reduced interest rates to restore stability. Our above-mentioned recommendations can be extended for global institutional reform. In that case, the central banks of member states would be superseded by a regional bank of reconstruction and development. In the case of the Islamic ummah such a global monetary reform can be guided by Islamic Development.

On this issue the International Monetary Fund has a standing idea. The IMF. U.S. Treasury Secretary muses on such a direction of monetary reform in the following words:

This is an important moment for the IMF and its future. The IMF has a critical role to play in the global resolution of the financial crisis. The proposed modernizing reforms 
IJMS 19 (1), 1-35 (2012)

will begin the process of making the IMF more representative of the global economy. It is strongly in the U.S. interest that the Fund fulfills these responsibilities in order to retain its relevance and preeminent place in the international monetary system. The need for a strong and effective IMF is all the more pressing in the challenging global economic environment we find ourselves in today. (http://www.treas.gov/press/ releases/hp1307.htm, U.S. Department of the Treasury, Deputy Assistant Secretary Sobel Remarks on the Global Financial Crisis and the IMF's Response, Dec. 2, 2008).

The above quote signifies the urgency of the time to launch the blueprint of a future reform of the monetary system in conjunction with the outlook of the real economy to gain global economic and financial stability. This paper has pointed out what structure of reasoning and institutional change will be required inside such an alternative form of money, finance and the real economy interlinked system in the Islamic economic and financial framework. 
IJMS 19 (1), 1-35 (2012)

\section{APPENDIX}

\section{THE PHENOMENOLOGICAL CONSTRUCTION OF THE ISLAMIC WORLDVIEW OF UNITY OF KNOWLEDGE: MONEY, FINANCE AND REAL ECONOMY COMPLEMENTARY LINKAGES}

We explain here the epistemological, ontological and evidential (ontic) constructs of the phenomenological model of unity of knowledge in the Islamic socio-scientific order. This is a complex and extensive field of inquiry. Details of the phenomenological have been examined by Choudhury (2006). Underlying all phenomena in Islamic intellection is this epistemological invoking of a systemic way of understanding oneness of the divine law at work. The phenomenological model of unity of knowledge is universal in the sense of its extensive explanatory and applicative capability. In the case of money, finance and real economy, the problem of unified interrelations has been explained in this paper.

As a general methodology, a tuple $(\theta \cdot x(\theta))$ (see Figure 3 ) is characterized within the general equilibrium system that simulates the learning relations between the elements of the tuple. q-values as flows of knowledge are generated within and across learning processes. They denote learning parameters that induce all variables endogenously. These are generated in reference to the epistemology of the unity of knowledge (Choudhury, 1997).

Several kinds of organic unity of the phenomenological system can be noted in Figure 3. These delineate the intra-process and inter-process dynamics and can be generalized to multiple systems by extension.

First, we note the unity of derived knowledge from the epistemological core within a discursive process to come up with the limiting value of knowledge-flow. This learning experience along with everything to follow represents endogenous relations caused by their induction by the knowledge-flow parameters, the q-values.

Only the epistemological core, $(\Omega, S)$ remains exogenous. This latter case is true both at the beginning and the end of the processes shown in Figure 3. Hence the Beginning is equivalent to the End, and the continuity over the Space, Time, and Knowledge domains is a closed one. ${ }^{8}$ 
Secondly, we note the organic unity of knowledge between the elements of the vector tuple. This pairing phenomenon is explained by the principle of pervasive complementarities together with the use of the functional ontological model of simulating the money, finance and the real economy interrelations. Besides, the same kind of construction applies for the organic unified interrelations by learning (discourse) between the central bank, the commercial banks (Islamic banks) and the $100 \%$ RRMS with the gold standard.

Thirdly, we note that within any process the phasing out of interest rates by trade instruments causes heightened resource mobilization. This brings about increased complementary relationships between resource mobilization and social well-being denoted by $\mathrm{W}(\theta, \mathbf{x}(\theta))$.

Fourth, learning by simulated complementarities between the elements of the tuple within any Process involves discourse over diverse possibilities (Interaction). Interactions lead to limiting the value of the learning parameter within a Process. This is the limiting knowledge-value, $\theta^{*}$. Attaining of $\mathrm{q}^{*}$ marks the phase of Integration (social consensus) emanating out of Interaction. At the end of any learning Process there comes about subsequent Evolution into the new learning processes. Evolutions arising from Interactions leasing into Integrations carry on the recursive learning processes in continuity over the knowledge-space-time domains. This is enabled necessarily and sufficiently by epistemological recalling of $(\Omega, S)$, as shown.

Fifth, the entire IIE-character of the learning process is universal and continuous by its extensions until the Hereafter. The Hereafter (Akhira) is described as the Great Event [9] in the Qur'an.

The all-inclusive IIE-model comprises the universal model of the unity of knowledge. It describes the phenomenological construction of the Islamic epistemological worldview in 'everything'. A scientific explanation of the concept of 'everything' is given by Barrow (1991).

Figures 1 and 2 in the text of this paper particularized the circular causation between money, finance and real economy in the case of a conscious transformation of Islamic monetary operation as a generalsystem framework of the creative purpose of the Shari'a (Maqasid alshari'a) for simulating social well-being. 


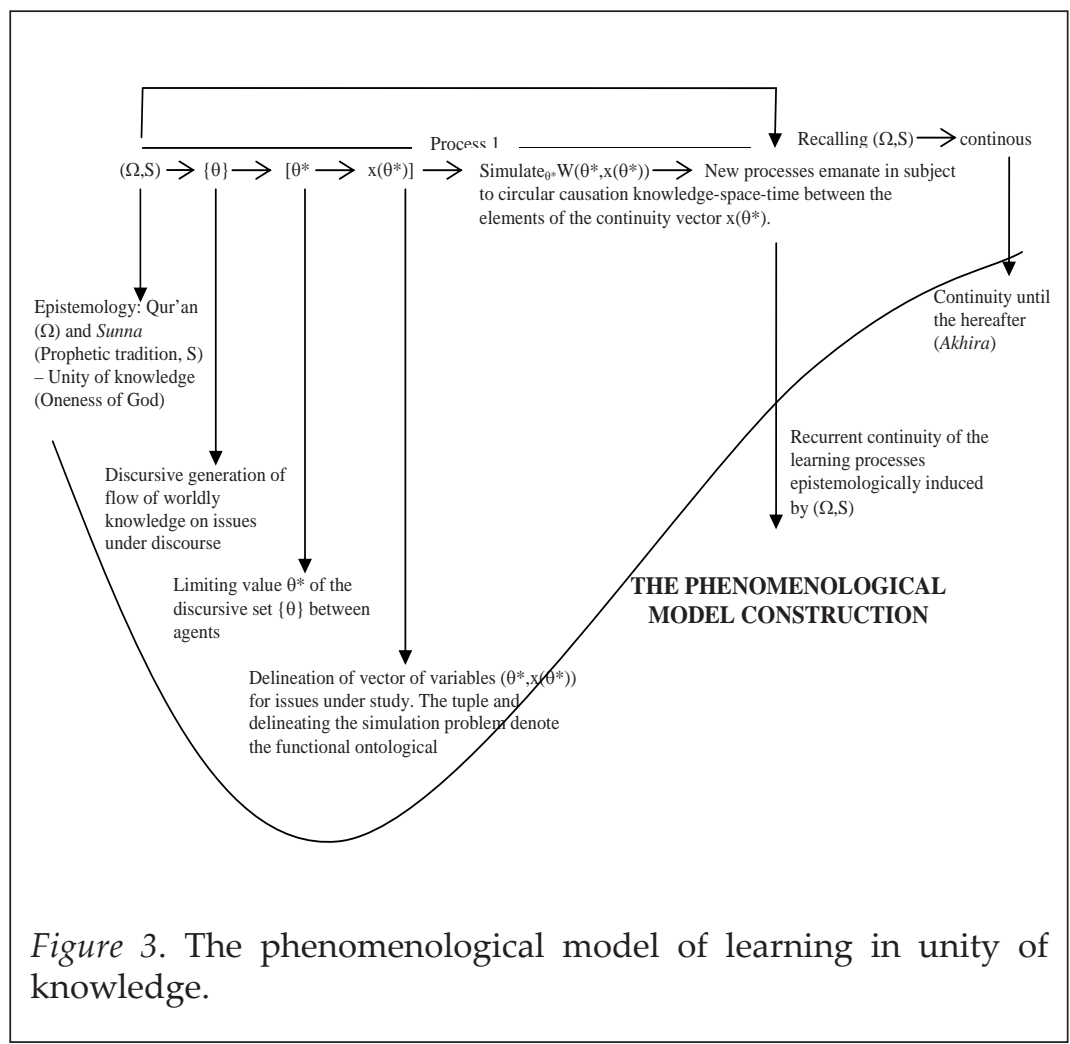




\section{End Notes}

1. In the suprime mortgage market, purchase price of the housing asset $<$ Present Value of discounted future cash-flows (capitalization). This phenomenon is well-known.

2. The 'own rate of interest $=\mathrm{D} \% \mathrm{p}_{c} / \mathrm{p}_{\mathrm{c}}$; ; where $\mathrm{p}_{\mathrm{c}}$ denotes current price of a commodity; $\mathrm{p}_{\mathrm{c}}^{\mathrm{f}}$ denotes future price of the commodity. The idea is that each commodity is intertemporally valued according to its own interest rates. But in the static equilibrium model, these divergent interest rates converge to a given rate.

3. The Qur'an declares (2:275): “... Allah has permitted trading and forbidden riba (interest)....'

4. $\quad$ Savings = Personal Income - Spending; whereas also the supply function is $S=S(i, I)$, $i$ : rate of interest. Hence, savings is that part of unspent income that is sensitively influenced by interest rate.

5. Assume $\mathrm{g}_{\mathrm{i} 1}=5 \% ; \mathrm{g}_{\mathrm{i} 2}=5 \%$ for $\mathrm{i}=1,2, . .$, n number of financed projects. For ten rounds of resource mobilization and regeneration through the commercial banks, the amount of money that will be created as a result equals $1000 \times(1.10)^{10}=2593.742$. For $n=$ 10 projects, the total quantity of money in circulation equals $10 \times 2593.74=25,937.42$.

6. These are the participatory development-financing instruments of mudaraba (profit-sharing) mushraka (equity-participation), murabaha (mark-up pricing), and questionably the secondary financing instruments and Islamic bonds called sukuk.

7. Functional ontology is the logical explanation of the being of a certain reality (e.g. mathematical model, logical formalism), as opposed to ontology taken in the metaphysical sense of the being of God or what Heidegger called Dasein. In Islamic belief we cannot work at the level of critical discourse of the latter. But functional ontology is accepted Islamic medium to unravel the unity of the divine laws at work in the world-systems. Functional ontology can be subjected to scientific discourse.

8. Qur'an (92:13): "And verily unto Us (belong) the End and the Beginning".

9. Qur'an (78:1-5): "What are they asking (one another) about? -- About the great news, (i.e. Islamic monotheism, the Qur'an, and the Day of Resurrection), about which they bare in disagreement. Nay, they will come to know! Nay, again, they will come to know!" Within this great event is embedded the meaning of the unity of divine knowledge and its relations with the world-systems in continuity till the end. 


\section{References}

Allouche, A. (1994). Mamluk economics, a study and translation of alMaqrizi's Ighathah. Particularly the chapter on "Currency [Islamic Currency"]. Salt Lake City, UT: University of Utah Press.

Bank Syariah Mandiri. (2006). Annual Report 2006. Jakarta, Indonesia. Bank Muamalat . (2007). Annual Report 2007. Jakarta, Indonesia.

Barrow, J. D. (1991). Theories of everything, the quest for ultimate explanation. Oxford, Eng: Oxford University Press.

Black, S. (1989). Seigniorage. In J. Eatwell, M. Milgate \& P. Newman (Eds.), New palgrave: Money (pp. 314-315). New York: W.W. Norton.

Blackwell, M., \& Nocera, S. (1989). Debt-equity swaps. In J. A. Frenkel, M. P. Dooley \& P. Wickhman (Eds.), Analytical issues in debt (pp. 311-345). Washington, D.C: International Monetary Fund.

Business Islamica. (March, 2008). Gulf mega-sukuk issues, a 'rich man's club. pp. 18-19.

Chapra, M. U. (1985). Towards a just monetary system. Leicester, UK: The Islamic Foundation.

Choudhury, M. A. (1989). Privatisation of the Islamic dinar as an instrument for the development of an Islamic capital market. Islamic economic co-operation (pp. 272-294 ). London: Macmillan. Choudhury, M. A. (1997). Money in Islam. London, Eng: Routledge.

Choudhury, M. A. (1999). A critique of econometric modeling for development studies: A political economy approach with special reference to Malaysia. In B.N. Ghosh \& M.S. Salleh (Eds.), Political economy of development in Malaysia (pp. 105-123). Kuala Lumpur: Utusan Publications.

Choudhury, M. A. (2006). The principle of complementarities in the Shuratic process and the implications for the socio-scientific order. The Koranic principle of complementarities applied to social and scientific themes (of 5 differently titled volumes), Chapter 1. Lewiston, New York: The Edwin Mellen Press.

Choudhury, M. A. (2008a). Islamic economics and finance: A fiasco. The Middle East Business and Economic Review, 20(1), 38-51.

Choudhury, M. A. (2008b). Islam versus liberalism: Contrasting epistemological inquiries. International Journal of Social Economics, 35(4), 239-268.

Choudhury, M. A. (2008-2009). Islamic asset valuation by using a terminal-value overlapping generation model, funded internal research project. College of Commerce and Economics, Sultan Qaboos University (mimeo). A part appeared in M.A. 
Choudhury (2011). Overlapping generation model for Islamic asset valuation: A phenomenological application. Chapter 8 of his Islamic Economics and Finance: An Epistemological Inquiry. Bingley, UK: Emerald.

Choudhury, M. A., \& Hoque, M. Z. (2004). Micro-money and real economic relationships in the 100 per cent reserve requirement and the gold standard. In their An advanced exposition of Islamic economics and finance (pp. 199-220). Lewiston, New York: The Edwin Mellen Press.

Choudhury, M. A., \& Zaman, Harahap, S. S. (2008). An evolutionary topological theory of participatory socioeconomic development. World Futures, 63, 584-598.

Choudhury, M. A. (2009). Money, finance and the real economy in Islamic banking and finance, perspectives from the Maqasid as-Shari'ah (Unpublished doctoral dissertation). Department of Economics, Banking and Finance Program, University of Stirling, Scotland. Donzelli, F. (2004). Rise and decline of the notion of own rate of interest in Sraffa. Working Paper No. 32. Universita degli Studi di Milano.

Friedman, M. (1968). Real and pseudo gold standards. In his Dollars and deficits (pp. 247-65). Englewood Cliffs, NJ: Prentice-Hall,

Gassner, M. S. (March, 2008). Revisiting Islamic bonds, are $85 \%$ of sukuk haram? Business Islamica, 22-23.

Green, R. (1989). Real bills doctrine. In M. Eatwell, Milgate \& P. Newman (Eds.), New palgrave: Money (pp. 310-313). New York: W. W. Norton.

Hayek, F. (1976). Choice in currency. Occasional paper 48. London, Eng: Institute of Economic Affairs.

International Monetary Fund (IMF) (2008, Dec 2). Retrieved from http://www.treas.gov/press/releases/hp1307.html.

Keynes, J. M. (1963). Economic possibilities for our grandchildren. Essays in persuasion (p. 368). New York: W.W. Norton.

Klein, B. (1975). The competing supply of money. Journal of Money, Credit and Banking, 4.

Krugman, P. R. (1989). Market-based debt-reduction schemes. In J. A. Frenkel, M. P Dooley \& P. Wickhman (Eds.), Analytical issues in debt (pp. 258-278). Washington, D.C: International Monetary Fund.

Money Matters. Retrieved from http://www.themoneymasters.com.

Mundell, R. A. (2000, Nov 8). Presentation at the economic forum on "One world, one currency: Destination or delusion? Washington D.C: International Monetary Fund.

Parker, M. (2012, Jan 3). Comments on al-Amine. M. al-Bashir's Global Sukuk and Islamic Securitization Market. Arab News. 
Ramsay, F. P. (1928). A mathematical theory of savings. Economic Journal, 543-550.

Rist, C. (1940). History of monetary and credit theory from John Law to the present day. London, UK: Allen Unwin.

Sauer, J. B. (2002). Meaning, method and social science, a realist account. Humanomics: International Journal of Systems and Ethics, 18(3/4) 101-113

Saving, T. R. (1977). A theory of the money supply with competitive banking. Journal of Monetary Economics, 3, 289-303.

Siven, C. (1978). The interaction between multiplier and inflationary processing. In S. Strom \& L. Werin (Eds.), Topics in disequilibrium economics. London: Macmillan.

Sraffa, P. (March, 1932). Dr. Hayek on money and capital. Economic Journal, 42.

Tobin, J. (1963). Commercial banks as creators of 'money'. In D. Carson (Eds), Banking and monetary studies (pp. 408-419). Homewood, ILL: Irwin.

Tullock, G. (1976). Competing moneys. Journal of Money, Credit and Banking, 7.

Usmani, M. T. (n.d). Usmani_Sukuk applications.pdf. Retrieved from http://www.failaka.com

Vogel, E. F., \& Hayes, S. L. (1998). Islamic law and finance: Religion, risk and return. Arab and Islamic Law Series, the Hague, Netherlands: Kluwer Law International.

Von, M. L. (1981). The return to sound money. The theory of money and credit. Indianapolis, IN: Liberty Fund, Chapter 23.

Von, M. L. (1976). The ultimate foundation of economic science. Kansas City: Sheed Andrews \& McMeel.

Wicksell, K. (1934). A mathematical analysis of Dr. Akerman's problem. Readings in mathematical economics: Capital and growth II (pp. 3-28). Maryland: The Johns Hopkins Press.

Yeager, L. B. (Spring, 1983). Stable money and free-market currencies. CATO Journal, 305-26.

Yeager, L. B. (1997). The fluttering veil. Indianapolis: Liberty Fund. 